Diabetologia $11,39-43$ (1975)

(c) by Springer-Verlag 1975

\title{
The Mechanism of Alloxan Toxicity: an Indication for Alloxan Complexes in Tissues and Alloxan Inhibition of 4-Acetamido-4'-Isothiocyanato-Stilbene-2,2'-Disulphonic Acid (SITS) Binding for the Liver Cell Membrane*
}

\author{
N. Bilić \\ Department of Physiology, Faculty of Medicine, University of Zagreb, Zagreb, Yugoslavia \\ Received: July 5, 1974, and in revised form: October 4, 1974
}

\begin{abstract}
Summary. It is shown that alloxan inhibits binding of SITS to liver cells. This indicates the cell membrane as a site of alloxan action. Alloxan is found to react with tissues to form complexes that are detectable up to $3 \mathrm{hrs}$ after alloxan treatment. On the basis of the present findings, an
\end{abstract}

assumption is made that alloxan inhibits a cell membrane processes by blockade of functionally important groups.

Key words: Alloxan, tissues, complexes, inhibition, binding SITS, assay, diphosphopyridine nucleotides, liver, kidney.
Although alloxan is widely used for induction of experimental diabetes, the mechanism of its diabetogenic activity and of its toxicity has so far remained unsettled.

Alloxan appears to be selectively toxic to the pancreatic beta-cells producing their necrosis [8]. At higher doses alloxan produces necrotic changes in other tissues as well $[8,10]$. However, at subdiabetogenic doses alloxan produces ultrastructural betacell changes that are quite similar in character to those observed after large doses [14]. These studies suggest that alloxan is toxic to tissues at any given dose, and that necrotic changes are related to tissue sensitivity and to amounts of alloxan injected.

Although morphological studies provide evidence for cell membrane damage [14], no conclusion could be drawn in regard to the primary site of alloxan action. Alloxan was shown to react with sulfhydryl groups [12]. Recent studies with toad-fish islets suggest that alloxan acts at or near the sugar transport site [13]. A theory was put forward that alloxan toxicity is based on inactivation of some critical enzymes containing active sulfhydryl groups [8]. Selectivity of alloxan for the beta-cells was explained either by a selective accumulation of the agent [4], or by relative deficiency of protective sulfhydryl groups in the beta-cells [8].

The present results show that alloxan forms complexes with tissue constituents. To show this effect, it was necessary to develop a specific assay for alloxan in tissues. This is fully described. Furthermore, it is shown that alloxan inhibits binding of SITS for the liver cell membrane. This suggests the cell membrane

\footnotetext{
* Supported by the Federal Research Fund
}

as a site of alloxan action. Also, it is shown that ratios of diphosphopyridine nucleotides in both liver and kidney remain constant over a few hours after alloxan treatment. This suggests that at least in these tissues energy metabolism is not primarily affected by alloxan.

\section{Materials and Methods}

Animals were albino rats of our random-bred Institute colony, that are descendents of Wistar rats. Animals were used at weights ranging from 180 to $250 \mathrm{~g}$. Unless otherwise stated, all reagents were of analytical grade.

\section{Alloxan Experiments}

Double glass-redistilled water was used for preparation of buffer solutions. These were charcoaltreated and kept frozen when not in use. Concentrated citrate-phosphate buffer $\mathrm{pH} 7$ was made by mixing 1 molar citric acid and 2 molar $\mathrm{K}_{2} \mathrm{HPO}_{4}$. The acidity was adjusted using a glass electrode. Citratephosphate buffer $\mathrm{pH} 4$ was prepared from 0.1 molar citric acid and 0.2 molar $\mathrm{K}_{2} \mathrm{HPO}_{4}$. This was used for preparation of alloxan solutions and for washing of talc columns after sample applications.

Alloxan solutions were prepared daily by dissolving alloxan in cold citrate-phosphate buffer $\mathrm{pH} 4$. orto-Phenylenediamine of chromatographic grade was dissolved in 0.1 normal $\mathrm{HCl}$ just prior to use at a concentration of $10 \mathrm{mg} / \mathrm{ml}$.

Talc of medical grade was used. It was repeatidly suspended in water and fines removed by aspiration. Talc was dried in an oven and stored at room tem- 
perature. Florisil $200-400$ mesh was prepared identically.

A day before use talc was suspended in water at a $10 \%$ concentration $(\mathrm{w} / \mathrm{v})$. While keeping talc in suspension with a magnetic stirrer, $2 \mathrm{ml}$ of the suspension was transfered into a glass column, $6 \times 100 \mathrm{~mm}$, having a Whatman fiber-glass disk as support. The talc was allowed to settled by letting water run out. Florisil was packed as such by pouring $100 \mathrm{mg}$ of the adsorbent into each column.

Under ether anesthesia, the right jugular vein was exposed and alloxan injected at a dose of $60 \mathrm{mg} / \mathrm{kg}$ body weight. Then a gastrocnemius muscle was exposed and the abdominal cavity opened by a medial incision. At times indicated in the experiment, tissues were sampled in the following order: kidney, pancreas, duodenal loop, liver, gastrocnemius muscle and lungs. A thread loop was placed around the left kidney hilus and tied. The upper pole was cut off and freeze-clamped with tongs precooled in liquid nitrogen. Then samples of other tissues were taken and cooled as well. Samples were kept in solid $\mathrm{CO}_{2}$, until weighing and homogenization were completed.

Each sample was homogenized in ice-cold water at a 5\% tissue concentration (w/v) using a glass-glass homogenizer. Homogenates were deproteinized with perchloric acid at a final concentration of 0.3 Normal. After centrifugation at $3000 \mathrm{rpm}$, each supernatant was passed through a Florisil column in order to reduce native tissue fluorescence. Acidity "vas adjusted to $\mathrm{pH} 4$ by adding a predetermined volume of concentrated citrate-phosphate buffer $\mathrm{pH} 7$. To this extract orto-phenylenediamine in a $0.01 \mathrm{ml}$ volume per $\mathrm{ml}$ was added. After $2 \mathrm{hrs}$ of incubation at room temperature in dark, extracts derived from alloxantreated tissues showed blue-greenish fluorescence when exposed to $365 \mathrm{~nm}$ light. In order to make measurements specific for alloxan, the alloxan condensation product (alloxan quinoxaline) was isolated by passing each incubate through a talc column. A band of blue-greenish fluorescence appeared on the top of adsorbent, whereas nonspecific condensation products showing blue fluorescence passed through.The band was rapidly eluated using $3 \mathrm{ml}$ of slightly alkaline media, for instance $20 \mathrm{mM} \mathrm{K}_{2} \mathrm{HPO}_{4}$. A blank for each sample was provided by subsequently eluting the column with additional $3 \mathrm{ml}$ of the eluent.

To test the reliability of this method of measuring alloxan in tissues, alkaline eluates were examined by chromatography on both Silica Gel G (Merck) and Chromar Sheet 500 (Mallinckrodt), which is $70 \%$ silicic acid and 30\% glass fibers. Developing solvents were buthanol, ethanol, acetic acid $(50: 20: 10 \mathrm{v} / \mathrm{v})$ for the former and 0.1 molar acetate buffer $\mathrm{pH} 4.6$, methanol $(50: 50 \mathrm{v} / \mathrm{v})$ for the latter system. Eluates derived from alloxan-treated homogenates or from tissues of alloxan-treated rats gave a single fluorescent spot in either chromatography, which fully corresponded to $R_{f}$ values of standard alloxan quinoxaline. $R_{f}$ values were 0.62 and 0.94 on Silica Gel $G$ and Chromar Sheet, respectively.

\section{SITS Experiments}

Fluorescence measurements of this dye is based on observations that the dye is practically nonfluorescent at $\mathrm{pH}$ values below 12 , and highly fluorescent in 2 Normal KOH (Marinetti and Gray 1967). Preliminary tests were made using liver tissue homogenized in 20 $\mathrm{mM}$ phosphate buffer $\mathrm{pH} 7.5$. To this the dye was added, and after $5 \mathrm{~min}$ of incubation precipitation was performed with perchloric acid. The precipitate showed weak fluorescence when dissolved in glycine$\mathrm{NaOH}$ buffer $\mathrm{pH} 12$ (50 mM in respect to glycine), and high fluorescence when dissolved in 2 Normal $\mathrm{KOH}$.

Rats were decapitated and their abdominal cavities opened; $10 \mathrm{mls}$ of ice-cold Krebs-Ringer-Phosphate buffer containing $100 \mathrm{mg} / 100 \mathrm{ml}$ glucose was injected into the liver through the portal vein. The middle lobe was removed, washed in Krebs-Ringer-Phosphate, blotted on filter paper and weighed. The tissue was cut into small pieces and pressed through a nylon mesh (pore size $1 \times 1 \mathrm{~mm}$ ) streched over a $50 \mathrm{ml}$ beaker. The tissue concentration was adjusted to $5 \%(\mathrm{w} / \mathrm{v})$ with the buffer. The tissue suspension was centrifuged at $1000 \mathrm{rpm}$ for 1 minute. The supernatant was transfered and centrifuged again at $3000 \mathrm{rpm}$ at $4^{\circ}$ for 5 min. The pellet obtained was suspended in the buffer to give a $10 \%$ tissue concentration on the basis of initial tissue weight. The cell suspension was distributed in $2 \mathrm{ml}$ volumes into plastic vials for incubation. Further details are given under the experiment.

Binding of SITS for liver cells was followed by transfering samples at times indicated in the experiment into $5 \mathrm{ml}$ volumes of 0.3 normal perchloric acid. After centrifugation the pellet was suspended in $5 \mathrm{ml}$ of the acid and centrifuged again. This pellet was dissolved in $3 \mathrm{ml}$ of the glycine- $\mathrm{NaOH}$ buffer. A $0.5 \mathrm{ml}$ volume was transfered into a fluorometer cell and made up to $1 \mathrm{ml}$ with the glycine- $\mathrm{NaOH}$ buffer. This served as a blank. A $0.5 \mathrm{ml}$ volume was transfered into another cell and made up to $1 \mathrm{ml}$ with 5 Normal KOH. This served as a sample.

\section{Diphosphopyridine Nucleotide Measurements}

These were measured by the enzymatic cycling procedure. Under light ether anesthesia, at times in- 
dicated in the experiment, tissues were frozen in situ using a clamp precooled in liquid nitrogen, and processed as recommended. Enzymes used were of Boehringer, Mannheim, Germany.

\section{Fluorometry}

A Farrand ratio fluorometer was used. Filter selections were as follows: In all measurements, excitation light was isolated using a $365 \mathrm{~nm}$ narrow-band inter-

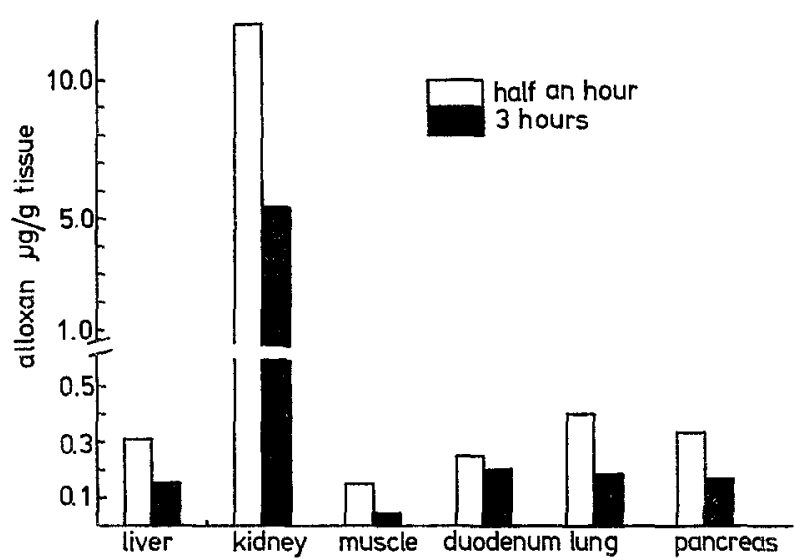

Fig. 1. Alloxan in rat tissues. Each value is a mean of 5 determinations

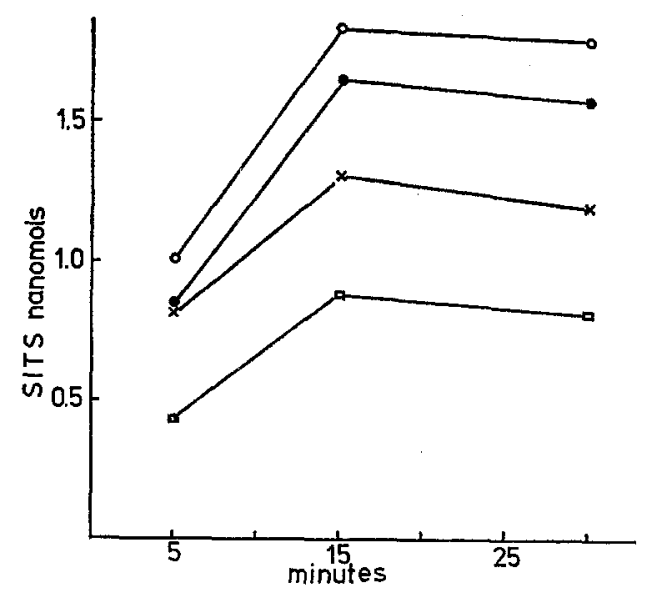

Fig. 2. Alloxan inhibition of SITS binding to liver cells. The different curves are: (o) control, (O) cells reacted with 0.01 $\mathrm{mM}$ alloxan, $(\mathrm{x})$ cells reacted with $0.1 \mathrm{mM}$ alloxan, $(\square)$ cells reacted with $1.0 \mathrm{mM}$ alloxan. To $2 \mathrm{ml}$ of the liver cell suspension in Krebs-Ringer-Phosphate buffer containing glucose $100 \mathrm{mg} / 100 \mathrm{ml}$, alloxan in $0.025 \mathrm{ml}$ volumes was added to give concentrations as indicated. Incubation continued for $\mathbf{1 5}$ minutes at $37^{\circ}$ with a shaking rate of 100 cycles per minute. Then SITS in a $0.025 \mathrm{ml}$ volume was added to each vial to give a $0.1 \mathrm{mM}$ concentration. Addition of SITS indicates time zero. Using a constriction pipette, a $0.1 \mathrm{ml}$ volume of the cell suspension was transfered from each vial into $5 \mathrm{ml}$ of 0.3 normal perchloric acid for assay of bound SITS. Each value is a mean from 3 incubation vials. The ordinate represents quantities of bound SITS per $0.1 \mathrm{ml}$ cell suspension ference filter. Fluorescence light was isolated using a $511 \mathrm{~nm}$ narrow-band interference filter for alloxan quinoxaline, a Wratten 58 filter (peaks at $525 \mathrm{~nm}$ ) for SITS and a Wratten 3 filter (sharp cut-off, passes wavelenghts above $455 \mathrm{~nm}$ ) for pyridine nucleotides. Fluorescence readings were made using $1 \mathrm{ml}$ pyrex cells.

\section{Results}

\section{Detection of Alloxan in Tissues}

Using the present procedure alloxan was found for $3 \mathrm{hrs}$ after alloxan administration in all tissues tested (Fig. 1). At half an hour after alloxan tissue concentrations ranged between 0.1 and $0.3 \mathrm{mg} / \mathrm{kg}$ of tissue, except in kidneys. In other words, it amounts to less then $1 \%$ of the dose given. Although these values seem to be low, they may be significant in regard to the mechanism of alloxan action. These results indicate that alloxan enters into reactions with tissues, otherwise it would not be possible to detect any because free alloxan undergoes fast decomposition with a half-life of less than one minute.

\section{Effect of Alloxan on Binding of SITS by Liver Cells}

Both with and without prior reaction of liver cells with alloxan, binding of SITS reached saturation within the initial $15 \mathrm{~min}$ of incubation. When liver cells were reacted with different concentrations of alloxan, binding of SITS was inhibited depending on the alloxan levels used (Fig. 2). When liver cells were reacted with $1 \mathrm{mM}$ alloxan, a 50\% decrease in binding of SITS was observed.

Although the mechanism of SITS binding is unclear, there are indications that about $10 \%$ is bound covalently and the remainder noncovalently [3]. Further, it was suggested that SITS inhibits transport of anions through the cell membrance by reacting with positively charged groups, possibly with amino groups having high $\mathrm{pK}$ values. How alloxan inhibits binding of SITS, is not known. It is possible that alloxan reacts rapidly with these amino groups, thus transforming them chemically into unreactive ones, or alloxan reacts with these groups to form complexes, thus making them unaccessible to SITS.

\section{Effect of Alloxan on Diphosphopyridine Nucleotides Concentration in Both Liver and Kidney Tissues}

Results are given in Tab. 1. Although the number of observations is insufficient for statistical treatment, it is clearly seen that a ratio of these nucleotides in 
both tissues remained more or less constant after alloxan treatment. This suggests that at least in these tissues energy metabolism is not primarily affected by alloxan.

However, in liver tissue, $10 \mathrm{~min}$ after alloxan treatment, there was a $20 \%$ decrease in total $\mathrm{nu}$ cleotide levels. In kidneys no change was observed. Reasons for this inconsistency are unknown, although both tissues were shown to be sensitive to higher doses of alloxan.

\section{Discussion}

Alloxan was shown to react with free sulfhydryl groups of proteins and with both reduced glutathione and cystein [12]. Although the mechanism of this reaction has not been fully investigated, it seems that oxi- in tissues over at least a $3 \mathrm{hr}$ period after alloxan treatment. This is in contrast with what one might expect on the basis of alloxan behavior in buffers [11]. However, the present results are in agreement with the interpretation that alloxan reacts with tissues to form complexes. Hence it is recovered by acid treatment of tissue samples in the course of analytical procedure. An assumption is made that alloxan toxicity is based probably on blockade of functionally important groups.

The present results show that alloxan inhibits binding of SITS to liver cells. Since the dye does not penetrate the cell membrane $[3,7,9]$, it is reasonable to conclude that alloxan acts at least at the level of cell membrane. The dye inhibits transport of anions through the cell membrane by reacting presumably

Table 1. Diphosphopyridine nucleotides concentration (micromoles/kg tissue)

\begin{tabular}{llrllllll}
\hline $\begin{array}{l}\text { Time after } \\
\text { alloxan } \\
\text { treatment }\end{array}$ & DPN+ & DPNH & Total & $\begin{array}{l}\text { Ratio of } \\
\text { DPN to } \\
\text { DPNH }\end{array}$ & DPN+ & DPNH & Total & $\begin{array}{c}\text { Ratio of } \\
\text { DPN to } \\
\text { DPNH }\end{array}$ \\
\hline control & 680 & 108 & 788 & 6.2 & 520 & 22 & 542 & 23.0 \\
& 620 & 164 & 784 & 3.7 & 420 & 52 & 472 & 8.0 \\
& 612 & 68 & 680 & 9.0 & 496 & 34 & 530 & 14.0 \\
& 658 & 82 & 740 & 8.0 & 437 & 54 & 491 & 8.0 \\
& 630 & 70 & 700 & 8.7 & 460 & 70 & 510 & 6.6 \\
\hline 10 minutes & 520 & 78 & 598 & 6.6 & 480 & 60 & 540 & 8.0 \\
& 510 & 88 & 598 & 5.8 & 500 & 52 & 552 & 9.6 \\
& 538 & 75 & 613 & 7.1 & 520 & 60 & 580 & 8.6 \\
\hline 30 minutes & 520 & 84 & 604 & 6.2 & 482 & 32 & 514 & 15.0 \\
& 556 & 106 & 662 & 5.2 & 472 & 52 & 524 & 9.0 \\
\hline 360 minutes & 630 & 84 & 714 & 7.5 & 452 & 40 & 492 & 11.3 \\
& 620 & 88 & 708 & 7.0 & 434 & 46 & 480 & 9.4 \\
\hline
\end{tabular}

dation of sulfhydryl groups takes place. In the course of this reaction, depending on incubation conditions, alloxan was shown to form complexes with reacting substances having absorption maxima either at 305 or $280 \mathrm{~nm}[12,15]$. Evidence was presented that a nitrogen base is involved in the reaction with alloxan [15].

It is of interest that, when using ortho-phenylenediamine as a reagent, alloxan could be recovered at least in part from alloxan-glutathione complexes ${ }^{1}$. This suggests that alloxan has not undergone a marked chemical transformation while in complex form. In agreement with this interpretation are findings that prior glutathione treatment increased blood alloxan levels in alloxan-treated rats [1].

The present results show the existence of alloxan

1 unpublished observations with positively charged groups $[3,7]$. Further, the dye inhibits binding of chloromercuribenzene-p-sulphonic acid for exposed sulfhydryl groups on the cell membrane [6]. Therefore, these observations support an assumption that alloxan inhibits binding of SITS for the cell membrane by a mechanism that involves reactions with both amino and sulfhydryl groups.

It was shown that alloxan increased permeability of toad-fish islets, whereas various sugars may prevent or even reverse this effect [13]. Furthermore, it was shown that glucose given prior to alloxan protects rats against diabetes [16]. These studies suggest that alloxan acts at the sugar transport site. Since sulfhydryl, amino and imidazole groups were shown to be essential for sugar transport [2], an involvement of these groups in the reaction with alloxan is therefore presumed. 
In the present studies a decrease in total levels of diphosphopyridine nucleotides in liver tissue was observed $10 \mathrm{~min}$ after alloxan treatment. This effect might be due to tissue edema including cell swelling. This is in agreement with the interpretation that alloxan affects the cell membrane functions including the transport processes, and therefore may induce disturbances in movements of both fluid and solutes through the membrane. However, both leakage of nucleotides due to cell membrane damage and increased degradation for some unknown reasons may account for this effect as well.

The mechanism of high toxicity of alloxan to the beta-cells is unknown. As already discussed, the present results support the concept that alloxan reacts with important chemical groups on the beta-cell membrane. High density of these groups on the surface of the beta-cells may account for their high sensitivity to alloxan. In agreement with this view are demonstrations that the beta-cell plasma membrane is rich in thiol groups [6], and that the beta-cells contain a carrier system for very, rapid transport of glucose [5]. This assumes high density of glucose "channels" whose structure involves chemical groups capable of reacting with alloxan. Furthermore, as shown by microautoradiography, mouse islets in vivo concentrate labelled alloxan [4]. This finding may be interpreted either in terms of high density of alloxan reacting groups on the surface of the beta-cell or in terms of alloxan accumulation within the beta-cell. The latter possibility assumes that alloxan shares a carrier system operating long enough to produce alloxan accumulation. However, this seems to be unlikely because alloxan reacting with carriers' functional groups may well inactivate their function.

\section{References}

1. Bilić, N., Felber, J. P.: Diabetogenic action of alloxan following temporary interruption of arterial blood flow to pancreas in rats. Diabetes 19, 81-84 (1970)

2. Bloch, R.: Human erythrocyte sugar transport. J. biol. Chem. 249, 1814-22 (1974)

3. Cabantchik, Z. I, Rothstein, A.: The nature of the membrane sites controlling anion permeability of human red blood cells as determined by studies with disulphonic stilbene derivatives. J. Membrane Biol. 10, 311 - 30 (1972)

4. Hammarström, L., Hellman, B., Ulberg, S.: On the accumulation of alloxan in the pancreatic beta-cells. Diabetologia $2,340-45$ (1966)

5. Hellman, B., Sehlin, J., Täljedal I. B.: Evidence for mediated transport of glucose in mammalian pancreatic betacells. Biochim. biophys. Acta (Amst.) 241, 147-54 (1971)

6. Hellman, B., Lernmark, A., Sehlin, J., Söderberg, M., Täljedal, I. B.: The pancreatic beta-cell recognition of insulin secretagogues. Binding and permeation of chloromercuribenzene-p-sulphonic acid in the plasma membrane of pancreatic beta-cells. Arch. Biochem. 158, 435-41 (1973)

7. Knauf, P. A., Rothstein, A.: Chemical modifications of membranes. Effect of sulfhydryl and amino reactive reagents on anion and cation permeability of the human red blood cell. J. gen. Physiol. 58, 190-210 (1971)

8. Lazarow, A.: Alloxan diabetes and the mechanism of beta-cell damage by chemical agents. In: Experimental diabetes, a symposium, pp. 49. Springfield: Charles $\mathrm{C}$. Thomas 1954

9. Marinetti, G. V., Gray, G. M.: A fluorescent chemical marker for the liver cell plasma membrane. Biochim. biophys. Acta (Amst.) 135, 580-90 (1967)

10. Patent, J. G., Alfert, M.: Histological changes in the pancreatic islets of alloxan-treated mice, with comments on beta-cell regeneration. Acta anat. (Basel) 66, 504-19 (1967)

11. Patterson, J. W., Lazarow, A., Levey, S.: Alloxan and dialuric acid, their stability and ultraviolet absorption spectra. J. biol. Chem. 177, 187-96 (1949)

12. Patterson, J. W., Lazarow, A., Levey, S.: Reaction of alloxan and dialuric acid with the sulfhydryl group. J. biol. Chem. 177, 197-204 (1949)

13. Watkins, D., Cooperstein, S. J., Lazarow, A.: Effect of alloxan on islet tissue permeability, protection and reversal by sugars. Amer. J. Physiol. 224, 718-22 (1973)

14. Wellmann, K. F., Volk, B. W., Lazarus, S. S.: Ultrastructural pancreatic beta-cell changes in rabbits after small and large doses of alloxan. Diabetes 16, 242-51 (1967)

15. Yesair, D.: Potential alloxan-diabetic compounds from the reaction of alloxan, glutathione and nitrogen bases. Biochem. Pharmacol. 19, 687-95 (1970)

16. Zawalich, W. S., Beidler, L. M.: Glucose and alloxan interactions in the pancreatic islets. Amer. J. Physiol. 224, 963-65 (1973)

Dr. N. Bilić

Eidg. Forschungsanstalt

für Milchwirtschaft

CH-3097 Liebefeld-Bern

Switzerland 